\title{
The evolution of agribusiness management values from labor to brain mechanism that shape leadership style
}

\author{
Kannapat Kankaew, ${ }^{1, *}$ \\ ${ }^{1}$ International College, Suan Sunandha Rajabhat University, 1 U-Thong Nok rd, 10200, Dusit, \\ Bangkok, Thailand
}

\begin{abstract}
The managerial values have been changed overtime, because of external environment situations. It is also shaping leadership style in each era of the changes. This article, the authors aim to review the managerial values changing overtime from agricultural, to industrial revolution, computerization, technology, and until today the digitalization era. In each era, there were various scholar proposed management concept and values. Presently, some concepts are still in use, and each concept requires different leadership styles that affecting to organizational performancestrive to success its goals. The most well-known leadership styles are transactional and transformational style. Today, in digital era where artificial intelligent applied and things change swiftly, unpredictably. The leadership style in this era, the authors proposed leader should transform to 'digitalizational leader'.
\end{abstract}

\section{Introduction}

[1] mentioned that Thailand's national policy has shifted from 1.0 to Thailand 4.0. It is can be explained that, the development model of 1.0 focused on agricultural, while 2.0 stressed on light industrial for instance weaving, canned food, drugs and medical equipment. The 3.0 development model emphasized on heavy industrial, and exportation of goods such as shipbuilding, train building, machinery. For Thailand 4.0, it is the development model that driving the country's economy by innovation, or technology adaptation.

By virtue of [2] promulgated the issue on Small and Medium Enterprise SME Revolution that SME 4.0 refer to the business that digitalized by employing technology connecting, controlling, and enhancing the machine communication to each other. It is the businesses will be driven by science, technology, innovation, creativity and knowledge which can compete on a global level.

Thus, it can be assumed that the new era of competitionwill integrate technology in all processing from the input until the outcomes, as well as using technology to capture the consumer behavior that changing continuously. The managerial values will be more focusing on the agility of knowledge transferring, analytical data into value information, the

*Corresponding author: kunnapat.ka@ssru.ac.th 
innovation and creation of new products and services. The leader shall be technology savvy, able to apply data analytics for strategic management, adaptability in the fastchanging environment, and knowing which data is useful nor worthless to organization. Meanwhile, leader has to encouraging the learning throughout organization, inclusive of motivating employee support firm's operation.

\section{Theoretical Analysis}

The occurrence of change, the fact that, is whirling every moment. Some are predictably, but mostly fluctuating and unforeseeable. Specifically, today where the world become flat as a global village, technology advancement enhances the change goes faster such as the data, the information, and knowledge. The word was set to this era of change namely 'disruptive technology' era. It is the technology that affected to all level of socioeconomic including, individual, group, organization, and countries. The word 'change' was defined as a new organizing and working guidelines. Change is a concept of modern management initiatives, such as knowledge management, the creation of a learning organization [3].

It is in accordance with [4] disclosed that technology dramatically influenced on organization to deal with pressure for agility and capability to create information technology infrastructure. Since, the traditional competition was transformed from product, quality to knowledge, data, and information of organization. The knowledge is momentous resource in this era of knowledge-based economy, in consequence of the fact that the knowledge was viewed as a raw material and intangible resources. It is existing in human capital of organization [5].

However, the knowledge has to be shared, revolutionized into resources for value creation and innovation by the use of technology supporting [6]. The challenge of modern organization is the leader has to create the organizational culture of sharing, creating and innovating. Besides, technology that shape the socioeconomic which currently is the actual problem of pandemic COVID 19 shaping, the business model, and human life span.

The word 'new normal', and social distancing have been raised widely. That is mankind will change their behavior in daily life, the business model would certainly be adapting in accordance with external environment, and the economic downturn. Hence, this academic article review aims to highlight on the managerial value from the past to present, and leadership style in the digital world, as follow;

The authors divided managerial values into five main paradigms, categorized by the specific time as follow;

1. From classical managerial values to industrial revolution, during 1880-1930, in this period [7] said the first period of the industrial revolution was influenced by thought of Adam Smith, who believed that the market mechanism and competition will control the economic activity effectively, and lead to the wealth. It is a giant change shifting from handicrafts to machinery. The managerial values emphasized on the effectiveness and efficiency, the organizational structure, and economic. It is the beginning of scientific management. The reputation organizational theorist [8] studied human physical movement, motivation to find the best way increasing the outcomes. Taylor separated the task into subsystem namely 'division of labor'. Another famous theorist in this period is Fayol, who believed that the organization success depends on the administrative capabilities of management rather than technical competence.

Where, [9] determined the managerial values hinged on logical arrangement of the task, the coordination, centralization, regulations. Thus, they proposed POSDCORB management model compose of planning, organizational management, human resources, directing, coordinating, and reporting process. 
2. During 1931-1960, the theorists stressed on human resources abilities. The scholars believed that human has dignity, pride and ability to improve. The managerial values of this era, then, focused on motivation, relationship between employees, social group that will lead to organization productivity. They determined the organization as a social system. For instance, Barnard believed that the authority exists when subordinates willing to cooperate, trust in capabilities, or the goodness of leadership rather than a person. It is called authority of leadership. Forasmuch as, McGregor has proposed that a good leader should be wellorganized, lead, control, and apply various type of motivations. Since, he divided human into two categories which was called theory $\mathrm{X}$ and $\mathrm{Y}$. The $\mathrm{X}$ refers to human need to be controlled, where the $\mathrm{Y}$ means each individual has their own motivation, and the individual can control themselves [7].

3. The managerial values in 1961-1970, in this era the computer was introduced, and has been used in management by statistic, information systems. Hence, there are a lot of changes in organization environment. The organization has to be aware of various factors affecting its performance both internal and external. The managerial values were the usage of statistic, mathematic model resulting from the computers. So that, the decision of management was called management science [10]. This period the organization was more flexible, open, adaptability according to the environment changes. [11] have proposed the concept that there is no organizational theory fit with every situation, and there is no one best system for managing. This is, later, well-known as contingency theory. So that, the management team has to practice in accordance with viable environment.

4. The managerial values between 1970-2000, the rise of computer capability was more advance. This resulted to global consumption, globalization, and networking. People can access to information; the external environment is more complex and uncertainty. The organization strategy, knowledge-based society has been introduced [7]. As well as, the balanced scorecard concept was proposed by [12] to assess firm's operation strategy on financial, customer, internal process, and learning and growth. The conceptual of management mainly focused to the changing external environment, learning organization, strategic analysis, and decision making from leader. The employees were seen as human capital or intellectual assets of organization. The human resources have been more considered to develop through training, formal education, mentoring, and accumulating from direct experiences [13].

5.The managerial in present day to the unforeseeable future; the sophisticated advancement of technology enhanced people connected every time, and everywhere. The smartphone was introduced that people can transaction any kind of activities via the mobile phone, while the social media not only allow people to learn and connect freely. On the other hand, people can trade without store, without bank note instead transferring. The digital currency has been proposed such as, Libra, Bitcoin. In addition, the government of China is now considering to issue digital currencies [14]. It is worth noticing that, if the digital currencies are used the money will flow in the economic system faster and quicker, just a simple touch smartphone. This means that the world is entering to digital world on and on. Currently, the whole world confronts with the pandemic COVID 19. It is a crisis that would make the clearer change of business model, and people life span in a digital world. As refer to [15] mentioned that medicine company with more than ten thousand employees switched to a hundred per cent remote working. Later, the company plan to change the business model to 30 per cent offline, and 70 per cent online. Furthermore, the survey of Mckinsey Global Institute revealed that there are around 375 million global workforces would change occupation or learn new skills due to the technology advancement which lead to automation and artificial intelligence. The survey, also, predict the future trends will occur including; distance economy by applying digitization to avoid physical interactions, clients will more use e-commerce, and digital talent-marketplace 
platforms among companies for talent exchange. Thus, the organization should create digital training programs to deliver digital content swiftly. Another sample of employing digital in managing the pandemic as [16] reported that Taiwan government integrates the database of immigration and customs to generate big data for analytics, and tracking quarantine by mobile phone during segregation period in a real time manner. In fact, the company like Google and Facebook are collecting the user data and can predict what an individual like, or to do next. However, from Mckinsey survey illustrated that some leaders do not know how to cope with the upskill and reskill for their workforces. Meanwhile, [17] expressed that people will be demotivated to work from home. Since, they will lose their working social life at the workplace. Specifically, in the pandemic period people fear of losing jobs.

Hence, from the above mentioned the author concluded shown in table 1 as follow.

Table 1. Summarization of five managerial values.

\begin{tabular}{|c|c|c|c|c|}
\hline Period & Managerial Values & $\begin{array}{c}\text { Reputation } \\
\text { Thinkers/ } \\
\text { Influences }\end{array}$ & $\begin{array}{c}\text { Management } \\
\text { Concept }\end{array}$ & Leadership style \\
\hline \multirow[t]{2}{*}{$\begin{array}{c}1880 \text { to } \\
1930\end{array}$} & \multirow{2}{*}{$\begin{array}{l}\text { highlight on } \\
\text { effectiveness and } \\
\text { efficiency, } \\
\text { organizational } \\
\text { structure, and } \\
\text { economic }\end{array}$} & Taylor & $\begin{array}{l}\text { Division of labor; } \\
\text { separate task } \\
\text { according to physical } \\
\text { movement }\end{array}$ & \multirow{2}{*}{$\begin{array}{c}\text { Close control, } \\
\text { human value as a } \\
\text { machine, directing, } \\
\text { hierarchy, } \\
\text { bureaucratic, } \\
\text { centralize }\end{array}$} \\
\hline & & $\begin{array}{c}\text { Gulik\&Urwic } \\
\text { k }\end{array}$ & POSDCORB & \\
\hline \multirow{2}{*}{$\begin{array}{c}1931 \text { to } \\
1960\end{array}$} & \multirow{2}{*}{$\begin{array}{l}\text { Human relation, } \\
\text { motivation, } \\
\text { organization as a } \\
\text { social system }\end{array}$} & Barnard & $\begin{array}{c}\text { Employees' } \\
\text { willingness to } \\
\text { cooperate depend on } \\
\text { their logical thought, } \\
\text { trust in leadership } \\
\text { capabilities }\end{array}$ & \multirow{2}{*}{$\begin{array}{l}\text { Focus on human } \\
\text { relation, treat } \\
\text { employees as a } \\
\text { human, lead rather } \\
\text { than direct, } \\
\text { motivation and } \\
\text { create socialized } \\
\text { environment }\end{array}$} \\
\hline & & McGregor & $\begin{array}{l}\text { Theory } \mathrm{X} \text { and } \mathrm{Y} \\
\text { reflecting two side of } \\
\text { human being both } \\
\text { diligent, self- } \\
\text { motivated and } \\
\text { laziness }\end{array}$ & \\
\hline $\begin{array}{c}1961 \text { to } \\
1970\end{array}$ & $\begin{array}{l}\text { Computer and statistic, } \\
\text { information system for } \\
\text { decision-making, } \\
\text { management science, } \\
\text { external environment } \\
\text { affecting organization }\end{array}$ & $\begin{array}{l}\text { Lawrence } \\
\& \text { Lorsh }\end{array}$ & $\begin{array}{l}\text { Contingency theory, } \\
\text { no one best } \\
\text { management concept } \\
\text { the organization has } \\
\text { to adapt in } \\
\text { accordance with } \\
\text { external environment }\end{array}$ & $\begin{array}{l}\text { Decision based on } \\
\text { statistic, } \\
\text { information } \\
\text { system, and } \\
\text { adaptability to the } \\
\text { external } \\
\text { environment }\end{array}$ \\
\hline $\begin{array}{c}1970 \text { to } \\
2000\end{array}$ & $\begin{array}{c}\text { Globalization, } \\
\text { networking, } \\
\text { knowledge-based } \\
\text { society, training and } \\
\text { development, human } \\
\text { as an intellectual asset }\end{array}$ & $\begin{array}{l}\text { Kaplan \& } \\
\text { Norton }\end{array}$ & $\begin{array}{l}\text { Balanced scorecard: } \\
\text { BSC model to assess } \\
\text { organization } \\
\text { strategies in the } \\
\text { aspect of financial, } \\
\text { customer, internal } \\
\text { process, and learning } \\
\text { and growth }\end{array}$ & $\begin{array}{c}\text { Emphasis on } \\
\text { human capital } \\
\text { development, } \\
\text { mentoring, } \\
\text { coaching, } \\
\text { decentralization, } \\
\text { autonomy, } \\
\text { transformational } \\
\text { leadership } \\
\end{array}$ \\
\hline
\end{tabular}




\begin{tabular}{|c|c|c|c|c|}
\hline $\begin{array}{c}2000 \text { to } \\
\text { date }\end{array}$ & $\begin{array}{l}\text { Influenced by the } \\
\text { advancement of } \\
\text { technology, artificial } \\
\text { intelligence, } \\
\text { communication } \\
\text { technology, external, } \\
\text { the digitalization } \\
\text { business; financial, } \\
\text { data analytics, crypto } \\
\text { currencies, the } \\
\text { unexpected trend of } \\
\text { natural disaster, } \\
\text { outbreak }\end{array}$ & $\begin{array}{c}\text { The customer, } \\
\text { and } \\
\text { technology } \\
\text { have a huge } \\
\text { affecting to } \\
\text { organization. }\end{array}$ & $\begin{array}{l}\text { The rise of new } \\
\text { management concept, } \\
\text { work from home: } \\
\text { anywhere, any places. } \\
\text { Some entrepreneur no } \\
\text { need physical store. } \\
\text { Online and social } \\
\text { media selling, } \\
\text { digitizational } \\
\text { economy and } \\
\text { financial. } \\
\text { Data and information } \\
\text { analytics. }\end{array}$ & $\begin{array}{l}\text { Digitalized- } \\
\text { leadership }\end{array}$ \\
\hline
\end{tabular}

Finally, it is worth noticing that from period one the management values of organization leader spotlighted on formal, rational efficiency, seeing human as a machine. Leaders are close control employees for effective performance. In period two, the leader's managerial value stressed more on human relation, motivation, organizational culture, and social grouping. It can be said that in this era the leader sees employees as a human being who needs motivation, social, safety, and relationship. And in period three, the management values highlighted on the integration of internal and external environment, the organization is an open system. For period four, the strategic thinking approaches, the holistic system operation, and decision making based on information technology [18].

In the era three and four, the computer system play a significant roles where global trade and the $\mathrm{Y} 2 \mathrm{~K}$ has influence on business. The networking, alliances and best practice have been applied in both public and private organizations. Lastly, in the current time the globe is in digital era that change human behavior to new normal, the business model re-shaping, the currency likely to be digital currency, flow of data and information hastily. The organization leader needs to prepare coping with the digital era.

\section{Conclusion and recommendations}

In summarization, from the first period of managerial values can be assumed that leadership style is task oriented and direct employee at work, or job-centered leader, while the second period of managerial values focused on human relation and motivation. Then, the leadership styles would be people-oriented behavior or employee-centered [19].

From the authors perspective, it can be said that the job-centered leader, task oriented and direct employee at work practices and leads people in organization exchangefor rewards. This type of leader can be called 'transactional', while people or employeeoriented leader will focus on motivation employees, having vision, and inspirational skills for the organization performance. This type of leader called 'transformational'. As based on contingency and situational leadership theories, the transformational leader is also anticipating of external environment changes. [20].

That is in the period three and four where the organization become an open system. Consequently, in period four where the computer was more sophisticated the organization intense competing on strategies, uniqueness, to be the first mover in the market. From the authors point of view, the leadership style that fit with this period is a strategic leadership [21] who capable of influence others to perform the task willingly for the growth of organization as planned both in short and long term. Moreover, the strategic leadership was composed of transactional and transformational styles [22]. The crucial approach of strategic leadership is the value, and crystalize visionary. They allow employees to make decisions, while the leaders will focus strategically on innovation, moving forward in the turbulence of changes. 
For the latest period five, the authors propose new leadership style namely 'digitalizational leadership' in digital-based era. It is the era that firm focuses on knowledge, learning, digitalized activities, data and information analytics for decision making. It is the era of most transaction can be done via smart phone, and the digital currency has been traded. Thus, the digitalizational leadership is a process of initiative, holistic thinking, and changed-oriented as [22] cited that a changed-oriented leader who is perspicuous a vision, optimism, open will for new knowledge, problem-solving, motivate and engage to organization change. Additionally, the digitalized leader should be technology savvy, having ability to import and interpret vital data, and strategically. Since in this era, [23] stated that it is the era of big data where the characteristic of data flow composes of $5 \mathrm{Vs}$ including, value data, velocity, veracity, variety of data and sources, and volume [24]. Hence, the leader in digital economy who should encourage subordinates digital learning and utilizing purposefully for organization. That is the ability to integrate human brain with AI mechanism objectively.

\section{References}

1. K. Ayuwattanachai, 1.0+4.0 new equation agriculture+corporate social responsibility (2017) http://www.posttoday.com

2. The Ministry of Industry (Thailand), SME revolution (2017) http://www.SMERevolution.com

3. P. Dawson, Understanding organizational change: the contemporary expereince of people at work (2003)

4. A. Tran et al., International Journal of Recent Technology and Engineering 8(2S11) (2019)

5. T. Barao, J.B. de Vasconcelos, A. Rocha, R. Pereire, IJIM 37, 735-740 (2017)

6. J-A. Johannessen, PPM 15 (2017)

7. P. Pathranarakul, Comtemporary public administration theory (2018)

8. F. Taylor, The principle of scientific management (1911)

9. S. Gulick, W. Urwick, Papers on the science of administration (1937)

10. J.M. Shafritz, J.S. Ott, Classic of organization theory (2001)

11. P.R. Lawrence, J.W. Lorsh, Organization environment interface (1970)

12. A. Př́vara, Migration Letter 16(2), 245 - 254 (2019)

13. K. Kankaew, JESR 9, 203-210 (2019)

14. H.L.T. Mai et al., International Journal of Recent Technology and Engineering 8(2S11) (2019)

15. S. Agrawal, A. De Smet, A. Reich, To emerge stronger from the COVID 19 crisis, companies should strat reskilling their workforces now (2020) http://www.Mckinsey.com

16. H. Yourex-West, Taiwan used cellphone tracking, big data to contain spread of COVID 19- should Canada do the same? (2020) http://www.globalnews.ca

17. L. McGregor, N. Doshi, How to keep your team motivated, remotely (2020) http://www.hbr.org

18. W.K. Hoy, G.C. Miskel, Educational administration: theory, research, and practice (2005)

19. M. Özsahin, C. Zehir, A.Z. Acar, SBS 24, 1546-1559 (2011) 
20. E. Ogbonna, L.C. Harris, IJHRM 11, 766-788 (2000)

21. H. Semuel, H. Siagian, S. Octavia, SBS 237, 1152-1159 (2017)

22. C. Siren, P.C. Patel, J. Wincent, TLQ 27, 653-670 (2016)

23. A. Ekambaram, A.O. Sorensen, H. Bull-Berg, N.O.E. Olssen, PCS 138, 851-858 (2018)

24. A. Onyusheva, E. Changjongpradit, EUrASEANs 3(10), $52-60$ (2018) 